\title{
Potential Number of Passenger and Performance Evaluation of Surabaya School Bus
}

\author{
Adhi Muhtadi ${ }^{1, a)}$, Sapto Budi Wasono ${ }^{1, b}$, Hitapriya Suprayitno ${ }^{2, c)}$ \\ \& Ervina Ahyudanari ${ }^{2, \mathrm{~d})}$ \\ ${ }^{1)}$ Civil Engineering Department, Universitas Narotama, Surabaya, Indonesia. \\ ${ }^{2)}$ Civil Engineering Department, Institut Teknologi Sepuluh Nopember (ITS), Surabaya, Indonesia. \\ Correspondent : ${ }^{a)}$ adhimuhtadi1974@gmail.com, ${ }^{b}$ sapto.budy@narotama.ac.id, \\ ${ }^{c}$ suprayitno.hita@gmail.com \& ${ }^{d)}$ ervinaa.ariatedja@gmail.com
}

\begin{abstract}
Surabaya school bus is one of public facilitiesassetsand itsperformance should be evaluated periodically. Because the school bus is a public asset, it necessary to process the facility asset management to maintain operational performance optimally and efficiently. The number of students who use the school bus declines from year to year. Therefore, it's necessary to study the current performance of school buses and the number of potential students who can use the Surabaya school bus. The method used to survey the number of students utilizing school buses and to conduct school bus performance research. School bus itinerary starts from Dukuh Menanggal Street down to Dharmahusada Indah Street and back to Dukuh Menanggal Street. There are 43 schools along the school buses route. Travel time observed was 1 hour and 10 minutes. The load factoraverage of the $1^{\text {st }}$ school bus in segment 1 (Dukuh Menanggal - RSI) is $78.67 \%$ while in segment 2 (RSI - SMKN 5) it reaches 96\%. The load factoraverage of $2^{\text {nd }}$ school bus for segment 1 reach $31.33 \%$ and for segment 2 reach only $8 \%$. The total number of students from 11 schools was 12,391 students. However, the number of passengers/day was only 38 students from the operational of two school buses. This indicates that many students were still reluctant to use school buses, so that school bus performance improvements are needed to attract high school and junior high school students.
\end{abstract}

Keywords : facility asset management, school bus, passenger potential, performance evaluation, Surabaya.

\section{PRELIMINARY}

Asset management is an efficient methodology to allocates resources fairly to achieve goals and objectives (Danylo \& Lemer, 1998). The Facility Asset Management Cycle consists of the following stages: facility planning, facility procurement, facility certification and inventory, facility usage, facility development and facility deletion. Asset Management Facilities recognize two levels of management: facility management and facility management organization management.The facility can be interpreted variously. Facilities can be interpreted as physicalobjects or non-physical objects. In general, related to Facility Asset Management, facilitiesinterpreted in two classification. First, the facility as a complementary installation for an infrastructure. Second, facilities as something needed for life, goodin the form of physical objects or non-physical objects.Facilities in the form of Physical Objects are needed for LifePhysical objects needed for everyday life, it can be very diverse intypes ranging from educational facilities, health facilities, sports facilities and so on.School bus 
facility is consists mainly of school bus, bus stop and bus repair place (Soemitro \& Suprayitno, 2018).

Surabaya school bus is the one of the public assets in the form of student transportation services and must be manage efficiently so it can be deliver the students to school safely, comfortably, economically and on time. The Surabaya school bus is the one of facility assets. It is necessary to assess the operational performance of school buses so the process of asset management of public facilities can be monitored and achieved the ultimate goal of serving the students optimally and efficiently.

The number of school bus passengers in 2010 to 2013 declined continously. In 2010 there were 25,200 students/year using school buses. In 2011, itdeclinedto 21,600 students/year.In 2012, it dropped to 16,800 students/year, and in 2013, it declined again down to only 14,400 students/year used school buses (Kusuma, 2015). If the number of passengers continues to decline, it is feared that the decline in passenger numbers was caused by the decline of the school bus services quality. So that students will not use school buses even though they are free of charge and will switch to other vehicles types. Therefore, research on Surabaya school bus performance evaluation is needed to answer these problems.

Surabaya School bus was started to be operated since 2003, nowadays it is sensed to be less reliable by junior high and high school students. Because school bus quantity is only four units and serve one route only. While the potential number of passengers actually quite a lot because it departs from South of Surabaya to East of Surabaya with mileage of $13.7 \mathrm{~km}$. The potential number of students from 5 schools in the High SchoolComplexArea reached 4195 students (Sekartadji, 2015). Along the Surabaya school bus route there are 43 schools withradius until 400 meters from the existing bus stop.So the potential number of students who can take advantage of the school bus could be much larger than the above finding. Therefore, it is necessary to do research onthe potential number of students who can use the Surabaya school bus. The researchresultsare expected can be used to improve the quality of Surabaya school bus services.

\section{RESEARCH METHODS}

The study used a questionnaire to determine the characteristics of Surabaya school bus usersand several performance indicators for school bus services.Questionnaires were distributed to school bus passengers just before the school bus departing from the Surabaya City Transportation Office. The influence area of school bus is set as 400 meters from bus stop, due to Minister of Public Woks Regulation No. 03/PRT/M/2014.

The survey for school bus performance was done on board from the bus school departure point on Dukuh Menanggal Street. Questionnaires are addressed to students who use school buses and the drivers. Questions posed are on the following data:

1. student address (based on village, district and city)

2. gender (male or female)

3. age

4. schooling level (Junior High School/Senior High School),

5. school name

6. vehicles used to go to school bus stops

7. vehicles available at home

8. if you don't use a school bus, what kind of vehicle wouldyou use? (private vehicle/ public transportation)

9. the cost of using a private vehicle to school and go home every day

10. When using public transport, what vehicles are often used? (mikrolet, city bus, ojek or other)

11. How many times do you have to change public transportation to go to the school? 
12. How much does it cost to use public transport togo to school and back home?

13. How much is your daily pocket money?

14. How long does the travel time between the house and the bus stop?

15. How long does the travel time between home and school when using a private vehicle?

16. How long does the travel time between home and school when using public transportation?

17. How long does the waiting time for school bus departure?

18. How many times do you use the school bus weekly?

19. What do you suggest about school bus operations?

While the questions for the drivers areas below :

1. School bus number plate

2. Departure hours from and arrival hours to Surabaya City Transportation Office

3. School bus routes

4. Location of school bus stops

5. The level of accidents that happened

6. The level of bus damage

7. The working duration of the driver

The survey was done on board and started from Monday, April 18 until Friday, April 22, 2016. The survey focused on bus routes, travel time, departure time and arrival time, waiting time (to inquire directly to students used the school bus), to know the location of bus stops and vehicles used by students to get to the bus stop, noted the number of students who use the school bus. Interviews with the drivers about the availability of school buses ready for operation and the number of school buses, find out where are the bus stop, and calculate the capacity of school buses for calculating the load factors for each school bus.

\section{DATA COLLECTION}

The school bus program in Surabaya actually has been in existence since 2003, when Surabaya get the Wahana Tata Nugraha awards from the Department of Transportation for the category of big cities. So the Ministry of Transportation of the Republic of Indonesia awarded four school bus units to the Surabaya City Government.

Right after getting four school buses, the Department of Transportation of Surabaya City was directly used them as school buses in Surabaya. School buses only operate in the morning to deliver students to school with free of charge. The goal of the school bus program in Surabaya was to reduce congestion in Surabaya and to reduce the number of student accidents. However, this program faced several obstacles from public transport drivers (MPU). Since it reduce the number of public transport passenger and income for public transport from the student sector. After facing the refusal of public transport drivers, the school bus program was suspended in Surabaya. It caused a lengthy discussion with public transport organizations, police, and other stakeholders.In 2007, a Regulation of the Director General of Land Transportation ie. SK.967/AJ.202/DRJD/2007 on technical guidelines for school transportation organization was issued. From 2008 to present, school bus programs can operate normally and have legal regulations.

The Surabaya school buses number at the start of operation (in 2003) was 4 units. Whereas in 2016, there were only 2 units of Surabaya school buses operate specifically for students. Because 1 unit was still in repaire and another unit was used to help people to move to Osowilangun flats. The first departure time of the school bus was 05.45 AM and the second 
departure time was at 06.00 AM. The first arrival time was 06.55 AM and the second arrival time was 07.00 AM.The Surabaya school bus route can be seen in Figure 1 below.

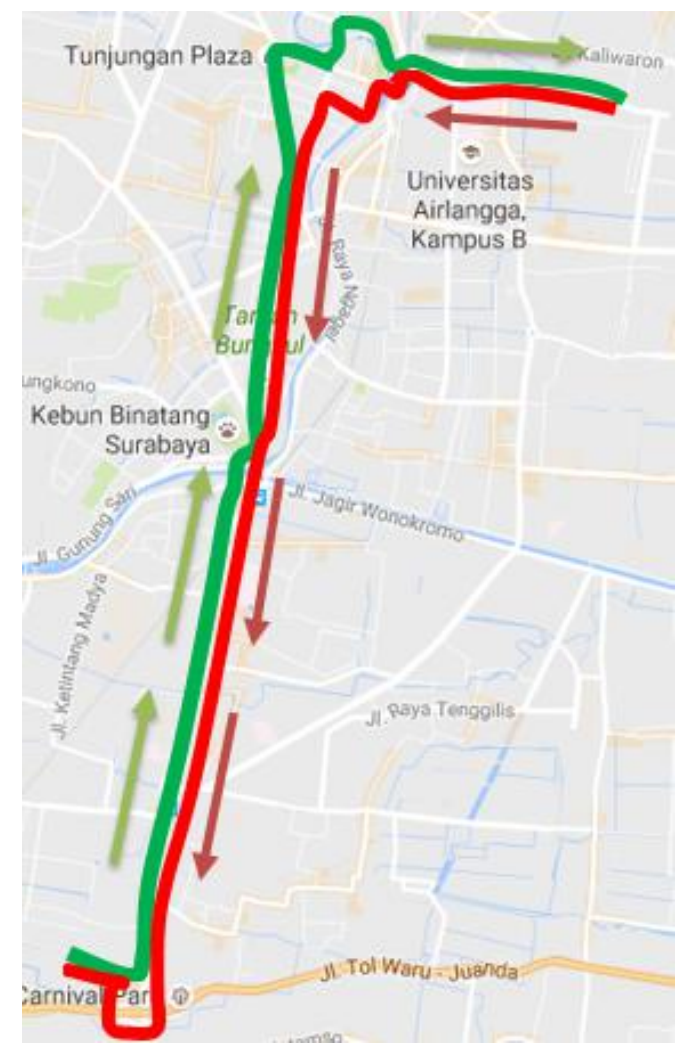

Figure 1. Surabaya School Bus Route

The school bus route was obtained from the results of field surveys that pass through the following roads: Office of Surabaya Transportation Department (Dukuh Menanggal Street) Ahmad Yani Street - Raya Wonokromo Street - Raya Darmo Street - Urip Sumoharjo Street Basuki Rahmat Street- Gubernur Suryo Street - Yos Sudarso Street - Sedep Malem StreetJimerto Street - BKR Pelajar Street - Selamet Street-Walikota Mustajab Street- Gubeng Viaduct - Prof. Dr. Moestopo Street - Dharmahusada Street-Turn Back - Dharmahusada Street - Prof. Dr. Moestopo Street - Gubeng Viaduct - Kayoon Street - Embong Kemiri Street - Panglima Sudirman Street - Urip Sumoharjo Street - Raya Darmo Street - Raya Wonokromo Street - Ahmad Yani Street - Waru Roundabout-Dukuh Menanggal Street.

The number of schools that can be served reach 43 schools. The schools were located in 6 sub-districts as follows: Gayungan sub-district (5 schools), Wonokromo sub-districts (13 schools), Tegalsari sub-districts (9 schools), Genteng sub-districts (10 schools), Gubeng subdistricts (3 schools), and Tambaksari sub-districts (3 schools). The potential number of students from 43 schools reached 25,533 students.

\section{RESEARCH ANALYSIS} below.

School Bus operational performance can be explained, in several points, as written

1. Operational Speed :

The average speed of first departing school bus was $22.49 \mathrm{~km} / \mathrm{h}$ and the second departing school bus was $26.47 \mathrm{~km} / \mathrm{hr}$. The standard speed for city transportation is 
between $25-30 \mathrm{~km} /$ hour. The average speed of the first school bus below the standard, while the speed of the second school bus accordance to the standard.

2. Headway

Headway between the first departing and second departing school buses was in average of15 minutes. Standard headwayduring peak hours should be between 5-10 minutes (Morlok, 1995). If the operational headway takes 15 minutes, that means the headway schedule should be shortened.

3. Passenger waiting time

The average waiting time for the first departing school bus was 6.84 minutes and the second departing school bus was 9.17 minutes. The average standard of passenger waiting time was 5-10 minutes (Abubakar, 1996). Sothe average waiting time for students was accordance to the standard.

4. Travel Distance

The traveling distance of school bus in one day was $26.24 \mathrm{~km}$. The standard for bus operation is $230-260 \mathrm{~km} /$ day (Warpani, 1990). So the distance school bus/day is in accordance with the standard.

5. Number of passengers carried every bus/day

The average first departing school bus was filled with 29 students and the average second departing school bus was only filled by 9 students. Students who used school buseswere very few. Standard states that the number of passengers bus/day ranges from 436-555 passengers/bus/day (World Bank, 1986). The number of students transported very few when compared to the existing standard.

6. Availability

Availability is the number buses in operation compared tothe total number of bus owned. This value describes efficiency and productivity level of each public transport, increasinglyThis low figure illustrates inefficiency in managementvehicle, and vice versa. Availability can be obtained withformula:

Availability $=\frac{N B O}{T N B O} \times 100 \%$

Where :

NBO : Number of buses in operation

TNBO : Total number of bus owned

The number of buses in operation is only 2 buses, while total number of buses owned is 4 buses. So the availability is only $50 \%$. According to the standard, the availability level should be in the range of $80-90 \%$ (Warpani, 1990). So thepercentagetotal buses for students were still below of the standard.

7. The distance between bus stops ( $300-500$ meter) (LPKM ITB, 1997)

There were two bus stops: (1) RSI Wonokromo, (2) BKR Pelajar Street (SMAN 9). Distance from the office ofDepartment of Transportation to Islamic Hospital (RSI)is 4.6 $\mathrm{km}$ and the distance from RSI toBKR Pelajar steetis $6.35 \mathrm{~km}$. Between Dukuh Menanggal Street- RSI issuburbs, while the distance between RSI to SMAN 9 is downtown.Because the stopping distance was too far, only a few students were use the school bus. So additional stops are needed, to serve different schools along the route of school bus.

8. Load Factor (70\%) (World Bank, 1986)

The Surabaya school bus has a seat capacity of 24 and a stand area for 6 people. The averageload factor of the first school bus from Dukuh Menanggal Street - RSI 
was $78.67 \%$ and average load factorfrom RSI - SMKN 5 was 96\%. Average load factor of the second school bus from Dukuh Menanggal Street - RSI Wonokromo was 31.33\% and average load factorfrom RSI Wonokromo - SMKN 5 was 8\%.The first school bus average load factor above $70 \%$, but the average load factorof second school bus is still below standard.

In Table 2, there are several schools and the number of students who use school buses. The total number of students from each school is also found in Table 2 below.

Table 2. The Students of School Bus Passenger

\begin{tabular}{cccc}
\hline No & School Name & $\begin{array}{c}\text { Number of } \\
\text { school bus } \\
\text { users }\end{array}$ & $\begin{array}{c}\text { Total } \\
\text { Students }\end{array}$ \\
\hline 1 & SMP Kemala Bhayangkari & 2 & 321 \\
2 & SMPN 32 & 3 & 866 \\
3 & SMP Santo Josef & 2 & 489 \\
4 & SMKN 1 & 6 & 2951 \\
5 & SMA Trimurti & 2 & 571 \\
6 & SMAN 6 & 1 & 923 \\
7 & SMPN 1 & 10 & 870 \\
8 & SMAN 9 & 2 & 987 \\
9 & SMAN 5 & 4 & 1016 \\
10 & SMAN 2 & 5 & 1105 \\
11 & SMKN 5 & 1 & 2292 \\
\hline
\end{tabular}

From Table 2 it can be seen that the number of students using free fare school buses is still very low. Only 38 students from the total of 12391 students. Therefore the performance of the school bus needs to be improved and a policy is needed so that students do not use private vehicles which can increasingly congested traffic in the city of Surabaya.

\section{CONCLUSION}

Some main conclusions can be drawn as follows. The movement of the school bus in terms of time and route are as follows.

1. The operation hour time of the first school bus: departure at 05.45 AM and back at $06.55 \mathrm{AM}$ so the travel time was 1 hour and 10minutes. The second bus operating hour: departure at 06.00 AM and back at 07.00 AM so travel time was 1 hour.

2. The school bus itinerary is: Surabaya Transportation Department (Dukuh Menanggal Street) - Ahmad Yani Street - Raya Wonokromo Street - Raya Darmo Street - Urip Sumoharjo Street - Basuki Rahmat Street - Gubernur Suryo Street - Yos Sudarso Street - Sedep Malem Street - Jimerto Street - BKR Pelajar Street - Selamet Street Walikota Mustajab Street - Gubeng Viaduct - Prof. Dr. Moestopo Street Dharmahusada Street - Turn Back - Dharmahusada Street - Prof. Dr. Moestopo Street - Gubeng Viaduct - Kayoon Street - Embong Kemiri Street - Panglima Sudirman Street - Urip Sumoharjo Street - Raya Darmo Street - Raya Wonokromo Street - Ahmad Yani Street - Waru Roundabout - Dukuh Menanggal Street.

3. School bus itinerary could actually reach 43 schools. However, only students from 11 schools used school buses. The overall potential number of students from 43 schools reached 25,533 students. While the number of 11 students in 11 schools is 12,391 


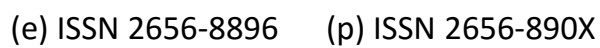
Journal of Infrastructure and Facility Asset Management - Vol. 1. Issue. 2, September 2019

students. The number of students who use school buses every day is still very small (38 students) or $0.15 \%$ from 25,533 students.

4. Average load factorfor first departing school bus is still good enough because the load factor is between $70.59 \%$ and $88.24 \%$. But the second departing school bus load factor in average was only $26.47 \%$ and $5.88 \%$. So additional bus stops should be installed to increase load factor of the Surabaya school bus.

\section{REFFERENCE}

Abubakar, Iskandar (1996). Menuju Lalu Lintas Dan Angkutan Jalan Yang Tertib. Direktorat Jenderal Perhubungan Darat. Jakarta.

Danylo, N.H. \& Lemer, A. (1998). "Asset Management for the Public Works Manager: Challenges and Strategies". Findings of the APWA Task Force on Asset Management, APWA, Washington, DC.

Departemen Perhubungan Republik Indonesia (2002). "Pedoman Teknis Penyelenggaraan Angkutan Penumpang Umum di Wilayah Perkotaan Dalam Trayek Tetap dan Teratur"

Dirjen Perhubungan Darat SK 967/A.J.202/DRJD/2007 tentang Pedoman Teknis Penyelenggaraan Angkutan Sekolah.

Kusuma (2015). "Evaluasi Program Bus Sekolah di Kota Surabaya”. Jurnal Kebijakan dan Manajemen Publik. (Vol. 3, No. 2, Hal.: 1-7). Sidoarjo.

LPKM-ITB (1997). Modul Pelatihan Perencanaan Sistem Angkutan Umum (Public Transport System Planning). LPKM-ITB.Bandung

Minister of Public Woks Regulation (2014). "Minister of Public Woks Regulation Number: 03/PRT/M/2014, PedomanPerencanaan, Penyediaan, dan PemanfaatanPrasarana dan Sarana Jaringan Pejalan Kakidi Kawasan Perkotaan"

Morlok, E.K. (1995). Pengantar Teknik dan Perencanaan Transportasi. Penerbit Erlangga. Jakarta.

Sekartadji, R., Widyastuti \& W. Herijanto (2015). "Study Demand and Supply Bus Sekolah Rute Dukuh Menanggal - SMA Kompleks Surabaya”. Seminar Nasional Sains dan Teknologi Terapan. Vol. III, Hal. 781-788.

Soemitro, R.A.A., \& Suprayitno, H. (2018). "Pemikiran Awal tentang Konsep Dasar Manajemen AsetFasilitas". Jurnal Manajemen Aset Infrastruktur \& Fasilitas, Vol. 2, Sup. 1, 2018.

Tamin, O.Z. (2000). Perencanaan dan Pemodelan Transportasi. Penerbit ITB. Bandung.

Warpani, P.S. (1990). Merencanakan Sistem Perangkutan. Bandung: Penerbit ITB

World Bank (1986). The International World Bank for Reconstruction and Development, Urban Transport. Washington. 
(e)ISSN 2656-8896 (p)ISSN 2656-890X

Journal of Infrastructure and Facility Asset Management - Vol. 1, Issue. 2, September 2019 